KEMAS 13 (3) (2018) 345-355
Jurnal Kesehatan Masyarakat

\title{
EFFECT OF CLIMATIC FACTORS AND HABITAT CHARACTERISTICS ON ANOPHELES LARVAL DENSITY
}

\author{
Noper Tulak ${ }^{1 凶}$, Handoko², Rini Hidayati² ${ }^{2}$ Upik Kesumawati Hadi ${ }^{3}$, Lukman Hakim ${ }^{4}$ \\ ${ }^{1}$ Jurusan Fisika, FMIPA, Universitas Cenderawasih \\ ${ }^{2}$ Departemen Geofisika dan Meteorologi, FMIPA, Institut Pertanian Bogor \\ ${ }^{3}$ Departemen Ilmu Penyakit Hewan dan Kesehatan Masyarakat Veteriner, FKH, Institut Pertanian Bogor \\ ${ }^{4}$ Pengendalian Penyakit dan Penyehatan Lingkungan, Kementerian Kesehatan RI
}

\begin{tabular}{l} 
Article Info \\
\hline Article History: \\
Submitted September 2017 \\
Accepted October 2017 \\
Published March 2018 \\
\hline Keywords: \\
rainfall, larval den- \\
sity, water temperature, \\
air temperature, salinity \\
\hline DOI \\
https://doi.org/10.15294/ \\
kemas.v13i3.11560
\end{tabular}

\begin{abstract}
Koya Barat village is one of the areas in Jayapura City which has high incidence of malaria. Malaria cases in this region are affected by local conditions, including the climate and environment of aquatic habitats. The purpose of this study was to analyze the effect of climatic factors and habitat characteristics on Anopheleslarval density in Koya Barat village. The method used is field observation with descriptive and statistical analysis approach.The results showed that there are four parameters that significantly affect on larval density, namely rainfall, air temperature, water temperature and salinity. The relationship between rainfall with the larval density in freshwater permanent habitat is negative linear. While in brackish water permanent habitat and semi permanent habitat is non-linear (2nd order polynomial). The relationship between air temperature, water temperature and salinity with the larval density in freshwater habitat are positive linear, while in brackish water habitat and semi permanent habitat are negative linear.
\end{abstract}

\section{Introduction}

Nowadays, malaria still become a serious community problem for some regions in Indonesia. It can reduce work productivity and resulting of mortality for high risk group which are baby, children under five years and pregnant mother. Malaria incident rate in Indonesia during $2012-2016$ tends to decrease with 1.69 per 1000 population in 2012 to 0.77 per 1000 population in 2016 (Ministry of Health, 2017). Though, malaria incident rate on east region of Indonesia still quite high particularly on Papua and West Papua province. Both are malaria endemic region with high case incidence (API $>5$ ) cathegory. Refer to Annual Paracite Incidence (API) in 2016, Papua province has highest API in Indonesia with 39.93 per 1000 population follows by West Papua with 10.20 per 1000 population.

Trend of malaria incidents on Papua provice during 2012-2016 were fluctuate time to time, which is 60.56 per 1000 population in 2012 became 42.65 per 1000 population in 2013. There was significant decrease in 2014 which became 29.57 per 1000 population yet the next two years increased to 31.93 per 1000 population in 2015 and 39.93 per 1000 population in 2016 (Ministry of Health, 2017). Based on the data, malaria is cathegorized as top 10 disease on the region. It scatters on nearly all region on Papua, including Jayapura which is the capital of the Province. One area on Jayapura having highest 
malaria incident is Koya Barat sub district, Muara Tami District. Medical record obtained from Koya Barat Community Health Service Centre (Puskesmas) showed that number of malaria possitive cases in 2014 are 1329 cases or 133.48 per 1000 population. Until June 2015 number of malaria possitive cases on this area had reached 721 cases.

The increase of malaria infection on Koya Barat is affected by local condition like climate, habitat, man behavior and mosquito population as the vector. In some cases, climate could have long term as well as short term effect to malaria transmission (Githeko, 2000). Rainfall is one of the most dominant climate factor affecting malaria infection since it has influence to number of habitat and population density of pre mature Anopheles mosquito (Zhou, 2004). The high or low of rain impact is depended on the intensity, number of rainfall and rain day, also from the physical characteristic of larva's habitat. On certain condition, rainfall could result an inundation for a long period of time thus provides a potention habitat for mosquito to breed. Whereas high rainfall could also wipe out pre mature mosquito, thus the vector population is reduced. So, the mosquito distribution will be limited while the condition is too dry or the rainfall is too high. On South Lampung, the density of malaria vector is founded highly related with rainfall on the month (Suwito, 2010). As well as the density of malaria vector on Sukabumi where it tends to be higher on rainy season (Hakim, 2007). Beside the rainfall, the temperature and humidity contribute to the infection of malaria (Duarsa, 2008). They increase mosquito's proportion to infect so that the possibility of contact with human.

The development phases of pre mature mosquito are taken place within aquatiq habitat thus they are directly affected by habitat characteristic which are the water physical, chemical and biological characteristic. Generally anophels sp mosquito's egg will hatch within 1-3 days on $30^{\circ} \mathrm{C}$ temperature and 7 days on $16^{\circ} \mathrm{C}$. In tropical region, the $16^{\circ} \mathrm{C}$ water temperature is the lowest temperature required by mosquito larva to develop while $36^{\circ} \mathrm{C}$ lasting for 2 consecutive months could eliminate all mosquito larva (Goswami, 2012).
The research in the laboratory results that an. gambiae larva can develop to mature mosquito in 10 to 38 days on constant $18^{\circ} \mathrm{C}-34^{\circ} \mathrm{C}$ water temperature (Bayoh, 2004). While in Kenya, it found to develop optimally on $4-6^{\circ} \mathrm{C}$ higher daily average water temperature (Paaijmans, 2010).

Considering the malaria infection is very specific on one place (local specific), then study result conducted on other region is uneffective when applied on other region. Beside, the variation of local climate/micro climate between one region with other geographic region will result different effect on malaria vector distribution. Until now, it has not been found out how the relation between climate factor variable and habitat characteristic and what factors affecting mosquito demographic of Anophels sp on Jayapura so that the infection risk is difficult to control. Therefore, this research objective is to analyze the effect of local climate factor and habitat environment characteristic to Anophels sp as malaria vector pre mature mosquito on Koya Barat district Muara Tami Jayapura. This research is expected to be able to provide information to the community and related instantion regarding climate and non climate factors supporting mosquito larva existance, so can be used as one alternative to compile more effective control strategy.

\section{Method}

This research taken time for a year from June 2014 - June 2015 on subdistrict Koya Barat district Muara Tami city of Jayapura. Geographical position of research location is on $140^{\circ} 46^{\prime} 58.18^{\prime \prime} \mathrm{EL}$ and $2^{\circ} 37^{\prime} 33.03^{\prime \prime} \mathrm{SL}$ with attitude 2 metres above the sea level. The research has been permitted by City of Jayapura Health Office with letter number: 440/1055/ PSDMK/2014.

The method used is a combination of observational, primary data collection and desk analysis. The research activity consist of larva taking, climate data observation, habitat characteristic data taking, larva rearing and Anophels sp identification. Tool and material used consist of $350 \mathrm{~mL}$ size larva scoop, digital water thermometer, digital $\mathrm{pH}$ meter, refractometer, plastic container, pipette, metre scale, one set of larva rearing tool, one set of mosquito pinning tool, stereo microscope, 
one set of climate data measure tool, GPS and digital camera. The research is started by initial survey for a week to determine potential larva habitat as obervation point. There are three kind of observed habitat which are freshwater permanent habitat (pool) having $15 \mathrm{~m}^{2}$ wide with maximum water depth $90 \mathrm{~cm}$, brackish water permanent habitat (lagoon) having $12 \mathrm{~m}^{2}$ wide with maximum water depth $45 \mathrm{~cm}$ and semi permanent habitat (puddles) having $3 \mathrm{~m}^{2}$ with maximum water depth $35 \mathrm{~cm}$. Those three habitats are choosen since they are considerred represent similar habitat on Koya Barat sub district.

Mosquito larvas are collected with $350 \mathrm{ml}$ plastic scoop. The frequention is once every four days for a years. It is based on the assumption that Anophels sp mosquito egg will hatch and develop to larva within one to four days since the mosquito spawn. Therefore on the time of larva collection will obtain developing mosquito larva from phase one. To reduce the mortality of breeded larvas, collection was conducted on the afternoo. Numbers of larva collection are depend on habitat wide and conducted equally from edge to center. Distance between first collection to the next is 1 metre. The larva of anophels sp mosquito catched is calculated the density then put in the botle and labelled for identification. Identification is conducted on entomology laboratory of Papua Biomedic R\&D with permission usage number HK. 05.01/XV/150/2015. The identification is assisted by Papua Biomedic R\&D entomologist using identification key from O'Connor and Soepanto. Then the number of species identification result is calculated based on habitat host type.

Analysis support data consisting of micro/local climate data and habitat characteristic data are measured every day for a year. A micro climate observation station has been designed to be installed closely with observed larva habitat. The measurement of air temperature, humidity and water temperature are conducted three times a day, on 07:00 am, 01:00 pm, and 6:00 pm. Where water $\mathrm{pH}$, salinity and rainfall are only measured once a day on 7:00 pm. The biology characteristic of larva habitat in the form of water plant and predator are directly observed. If there is water plant, it will be identified based on the variety. The density of water plant is cathegorized as very high when $>75 \%$ of water is covered by the vegetation, high when $>50-75 \%$ is covered, average when $25-50 \%$ is covered and rare for $<25 \%$ is covered. While the predator only noted for the species.

Analysis phase is started by calculate larva density (LD) of Anophels sp mosquito with below equation :

$$
\text { Larva Density }(\mathrm{LD})=\frac{\text { Number of larva taken }}{\text { Number of taking }}
$$

Next phase is to calculate average of air temperature, humidity and water temperature with general equation below :

$$
\bar{X}=\frac{2 X_{7}+X_{13}+X_{18}}{4}
$$

$\bar{X}=$ average value of each climate parameter and environment parameter (air temperature, humidity and water temperature)

$X_{7}, X_{13}, X_{18}=$ Observation time of each climate parameter and water temperature on 07:00 am, 01:00 pm and 06:00 pm

Then the climate data and habitat characteristic data are grouped into daily data and 3 days until 21 days average before larva collection with 3 days time interval. This is consider the development phase of Anophels sp mosquito larva on aquatiq habitat takes time within the time interval. Next step is to do descriptive analysis and statistic test with trust level 95\% ( $\alpha=0.05)$ to find out the sigification of relation between climate parameter and habitat characteristic with Anophels sp mosquito larva density. The significantly related variables are furtherly analyzed by linear regression or nonlinear form of order 2 polinomial. The enormity of climate factor and environment characteristic effect to larva density level is determined based on coeffisient value resulted by linear or nonlinear regression.

\section{Result and Discussion}

Generally, the climate on Jayapura region is wet tropical with monsunal rain type. Though the type is monsunal, the pattern of rain and dry season alternate oftently irregular due to the effect of local topographic condition. During the research, the rain on Koya Barat 
falls monthly with variation in duration and intensity. Average measured rainfall in June 2014 until June 2015 is $218 \mathrm{~mm} / \mathrm{month}$. While the highest was in December 2014 which was $336 \mathrm{~mm} / \mathrm{month}$ and the lowest was in June 2015 which was $131 \mathrm{~mm}$. Number of rainy days along observation period are 150 days with averagely 12 days per month. Highest was in February 2015 with 16 rainy days and lowest in November 2014 with 6 rainy days. For average air temperature measured is between $27.6^{\circ} \mathrm{C}$ until $28.3{ }^{\circ} \mathrm{C} /$ month with average air humidity between $78 \%$ until $82 \%$ / month.

Beside climate variation, habitat characteristic measured on Koya Barat also vary eventhough does not so different one to another. The most prominent difference only on water salinity, current type, habitat wide and water depth. The result of chemical characteristic measurement indicates that only lagoon having salinity since the position that near to the beach so it oftenly interact with sea water during the tide. Salinity measured in the lagoon is always vary depend on rainfall rate, sea water tide and water temperature. Generally salinity will increase after sea water tide that does not come along with rain. While water $\mathrm{pH}$ value measured on each habitat is still normal and acceptable by Anophels sp mosquito larva. While biological characteristic consists of aquatic animals and vegetation that nearly similar on all habitat with variation in species and density. Water vegetation is one of supporting factor to life preservation of mosquito larva in aquatic habitat as a coverage media (Mardiana\& Febrianto, 2009). Beside protect the larva from predator, it also prevent egg from rainfall and hold the larva from water current during heavy rain.

As biological characteristic, physical characteristic also indicates that there are similarity for several paramenters on all habitat such as water clarity, habitat bed and minimum water temperature (in the morning). While maximum water temperature (in the afternoon) and type of water current tend to vary one to another. Generally variation in water temperature is caused by volume of the puddle and duration of sunlight exposure. The less puddle volume and the longer of sunlight duration, then temperature range between morning and afternoon will be larger particularly on shallow puddle. Beside, the water temperature increase is tended to vary along with air temperature. The higher air temperature then water temperature will also increase even though the water temperature increase does not as fast as air temperature increase as water spesific heat is higher.

Based on water current type, pool and lagoon have closed current while puddle has open current. The consequence of current type is the effect on volume and duration of inundation of each habitat. On closed current, water does not have access to flow out of the habitat unless the rainfall intensity is larger

Table 1. Characteristic Comparation of Anophels sp Mosquito Larva Habitat on Koya Barat Subdistrict

\begin{tabular}{llll}
\hline Habitat Characteristic & \multicolumn{2}{l}{ Kind of Habitat } & \\
\cline { 2 - 4 } & $\begin{array}{l}\text { Permanent fresh } \\
\text { water (pool) }\end{array}$ & $\begin{array}{l}\text { Permanent brackish } \\
\text { water (lagoon) }\end{array}$ & $\begin{array}{l}\text { Semi Permanent } \\
\text { (puddle) }\end{array}$ \\
\hline Wide $\left(\mathrm{m}^{2}\right)$ & 15 & 32 \\
Water depth $(\mathrm{cm})$ & $85-90$ & $30-45$ & $5-35$ \\
Water current type & Closed & Closed & Open \\
Water clarity & Clear to muddy & Clear to muddy & Clear to muddy \\
Water temperature $\left({ }^{\circ} \mathrm{C}\right)$ & $29.9-31.1$ & $30.0-33.4$ & $30.8-34.5$ \\
Habitat bed & Mud & Mud and sand & Mud \\
Water pH & $6.9-7.1$ & $6.9-7.0$ & $7.0-7.2$ \\
Water salinity $(\% \circ)$ & 0 & $0-17$ & 0 \\
Vegetation type & Kale, algae and & Water grass, serasa & Kale and water grass \\
& water grass & & \\
Vegetation density & Rare to average & Rare & Very rare \\
Predator & Fish and Tadpole & Water spider & Fish and Tadpole \\
\hline
\end{tabular}

Source : Primary Data 


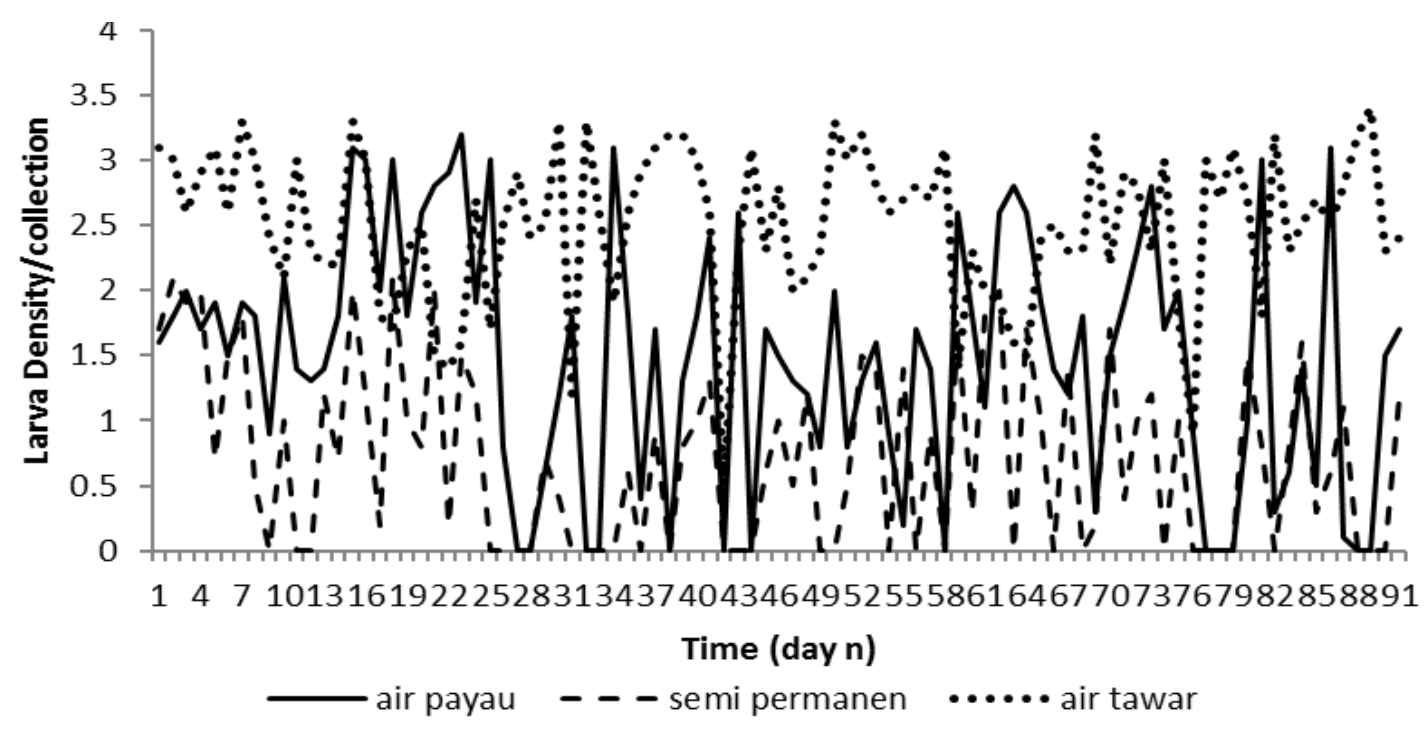

Picture 1. Fluctuation of Anophels sp mosquito larva density on lagoon, pool and puddle habitat

than habitat capacity. On the opposite, on open current water always has access to flow out. This results that larva's habitat will be lack of water when it does not rain and will have a runoff when raining eventhough in average intensity. The characteristic variation of Anophels sp mosquito larva habitat on Koya Barat, can be seen on table 1.

Generally, climate condition and characteristic of larva habitat measured on Koya Barat subdistrict are able to support the breed and dispersion of Anophels sp mosquito as malaria vector directly or indirectly. Fluctuation of rainfall intensity affect the numbers of habitat and puddle volume thus directly affect the existance of pre mature mosquito in aquatic habitat. Based on observation result, the density of Anophels sp mosquito on Koya Barat is depend on fluctuation of rainfall. Highest larva density is found on fresh water permanent habitat which is $0.5-3.4 /$ collection, then brackist water permanent habitat with $0-3.2 /$ collection and the lowest is semi permanent habitat with $0-2.4 /$ collection (picture 1 )

Picture 1 shows that Anophels sp mosquito larva respond to fluctuation of rainfall is vary on each habitat. The larva existance on fresh water habitat takes place all the time during this research while on brackish water and semi permanent habitat, larva only found out on certain condition of rainfall. This proof that rainfall has very important role in determining life preservation of Anophels sp mosquito larva in aquatic habitat. The high or low rainfall highly affect the volume and duration of puddle on each habitat. Generally puddle always available on permanent habitat though there is not rainfall while on semi/non permanent habitat, volume and duration of puddle is highly determined by rainfall amount. Water puddle that always available on fresh water permanen habitat facilitate the mosquito to lay egg every time untill develop to larva if sustains by habitat environment condition. Though, density of the larva in the habitat fluctuates as rainfall amount. Generally, mosqito larva density increases while it does not rain and decrease along with the increase of rainfall. The density of Anoplhels sp mosquito larva on fresh water permanen habitat tends to be affected by 6 days average rainfall before larva collection. Though the habitat always filled with water and longer duration. Generally larva density is decreased along with increased of average rainfall start from $15 \mathrm{~mm} /$ day. The higher quantity of rainfal has negative affect to larva density as it can devastate the eggs and flush out the larva when the water runoff. On the opposite average rainfall below $15 \mathrm{~mm} /$ day is optimum condition for egg and larva 
development. Water vegetation grows in the habitat is one of the factor supporting the preservation of mosquito larva since it protect from rainfall or predator.

Unlike the freshwater permanent habitat, effect of rainfall to larva on semi permanent habitat tends to be more sensitive. The rainfall on collection day directly influence the density. The higher rainfall, the less larva found even in certain condition, no larva able to preserve in the habitat. Same result when the rain does not fall in few consecutive days. Based on observation result, density of Anophels sp mosquito larva in semi permanent habitat is morely affected by 3 days average rainfall before larva collection. Optimum rainfall supporting the larva life preservation is between $5-10 \mathrm{~mm} /$ day. Rainfall intensity lower than $5 \mathrm{~mm} /$ day for 3 consecutive days will result a decrease in water volume, thus many mosquito larva is devastated. The rainfall higher that $10 \mathrm{~mm} /$ day for 3 consecutive days will flush out the larva. Shallow habitat condition with open current causing semi permanent habitat is very responsive to rainfall so that directly affect the preservation of mosquito larva.

Beside the rainfall, water temperature also one of environment factor that dominant to larva density in semi permanent habitat. The decrease of water volume on certain level always follow by water temperature. Generally larva density on this habitat will decrease along with the increase of average 3 days maximum water temperature (in the afternoon). The increase of water temperature start from $33^{\circ} \mathrm{C}$ for 3 consecutive days causing many mosquito larva devastated. The indication is marked with the decrased of larva density on next collecting day. Though in ideal condition on laboratorium, there are certain larva species able to develop well on water temperature above $33^{\circ} \mathrm{C}$ (Bayoh, 2004), yet this is different then the natural habitat. The semi permanent habitat that shallow with rare water vegetation cause the habitat is consecutively exposed direct sunlight so that many larva unable to survive when water temperature increase. Yet, on certain condition, the decrease of water temperature does not instantly follows by the increase of larva density. Like when heavy rainfall, water temperature decrease but still the collected larvas are low since they are wasted by water current.

As on fresh water permanent habitat, larva density on brackish water habitat tends to be affected by 6 days average rainfall before the larva collection. Optimum rainfall that able to increase larva density is between $10 \mathrm{~mm}-15$ $\mathrm{mm}$ /day while rainfall lower than $10 \mathrm{~mm}$ /day for 6 consecutive days or higher than $15 \mathrm{~mm} /$ day for 3 consecutive days can reduce larva density. Though the habitat has closed current type, yet the habitat bed which consist of sand causing larger infiltration so the water volume is decreased rapidly. Beside, the lack of water vegetation can make higher evaporation. This lead to increased water temperature and salinity thus affect the Anophels sp mosquito larva. Meanwhile, high rainfall more than 15 $\mathrm{mm} /$ day can harm the eggs and waste the larva. The undeep condition can't conserve the rain water thus the wave spill repeatedly occured. The higher the rainfall, then the higher the wave spill will be. Then more eggs and larvas are carried by water current. Even all larvas will be washed out during rainfall higher than 30 $\mathrm{mm}$ /day or sea tide.

Beside the rainfall, there are two other parameters directly affect to mosquito larva density on brackish water habitat which are water temperature and salinity. Generally water temperature will increase along with the decrease of rainfall volume since the water decreasing. Water temperature increase are always follow by salinity increase. The higher water temperature, then salinity value will increase as well (Abowei, 2010). Then, the combination between water temperature and salinity will higher affect the larva density. On certain level, both parameters can waste most of mosquito larva. Event on extreme condition there will no larva survive. Based on observation, larva densit on brackish water habitat begin to decrease along with the maximum increase of water temperature (afternoon) which is 32.0 ${ }^{\circ} \mathrm{C}$ because on that temperature, water salinity begin to increase.

High salinity can eliminate the larva particularly the species that can't adapt with the salinity. It indicated with less collected larva. Generally, mosquito larva density on brackish water habitat begin to decrease along with the 
increase of salinity value reach $7 \%$. The larva mortality reach the tip when salinity higher than $12 \%$ (picture 6 ). Few days after rain, water temperature and salinity gradually return to normal so that the collected larva density begin to increase. Yet there are certain times when salinity value reduction and water temperature do not come with larva density increase since many mosquito eggs and larvas are wasted out by water current.

The effect of salinity to Anophels sp mosquito larva is vary between species and geography area. The Anopheles sundaicus and subpictus larva on Nunukan, Estern Borneo are found to be able to survive on $24 \%$ salinity (Sugiarto et al., 2016). While in Sri Lanka, the Anopheles subpictus mosquito larva is found on 30\%o salinity (Surendranet, 2011). While on Maluku Tenggara Barat, Anophels sp larva is found on 0-1\%o salinity (Sandyet, 2017). On this research the Anophels sp larva living on lagoon habitat with salinity lower than $12 \%$. Suspected that combination between water temperature and salinity cause the larva more sensitive to salinity.

Refer to above, rainfall is a climate factor plays significant role in determining the live preservation of pre mature mosquito on aquatic habitat on Koya Barat while air temperature and humidity is support factors. Air temperature and humidity give more effect to mature mosquito live on terestrial habitat, include the activities of blood suction and egg maturing process (Epstein, 1998). Though, there is interdependence between larva density and mature mosquito population. More mosquito lay eggs on a habitat, then more larva density when rainfall condition and the environment support. Then the population or mature mosquito will increase when pre mature mosquito able to complete the development cycle completely. As well as climate factor, there are two habitat characteristic parameters play important role on Anophels sp mosquito larva density on Koya Barat which are water temperature and salinity while other factors as supporting one.

Statistic test result indicates that there are 4 measured parameters significantly affect Anophels sp mosquito larva density on validity level 95\% ( $\alpha=0.05)$, eventough the effects are vary on each type of habitat. The four parameters are rainfall, air temperature, water temperature and salinity. The rainfall significantly affect larva density before the day of larva collection until average 15 days. While air temperature is significant on average 9 days until 18 days. Next water temperature and salinity are significant on average 3 days and 6 days until larva collection (table 2).

Based on probability value (pvalue $<\alpha$ ) on table 2, the rainfall significantly affect the larva density on fresh water habitat start from average 3 days until 15 days before larva

Table 2. Result of Climate Factor and Habitat Characteristic Signification Test on Anophels sp Mosquito Larva Density on Three Type of Habitat

\begin{tabular}{|c|c|c|c|c|}
\hline \multirow{3}{*}{$\begin{array}{l}\text { Climate factor and } \\
\text { habitat characteristic }\end{array}$} & \multirow[t]{3}{*}{ Data Group } & \multicolumn{3}{|l|}{ p-value } \\
\hline & & permanent & semi & permanent \\
\hline & & fresh water & permanent & brackish water \\
\hline \multirow[t]{4}{*}{ Rainfall } & $\begin{array}{l}n=1 \text { day } \\
n=3 \text { days }\end{array}$ & $\begin{array}{l}0.128^{*} \\
0.000\end{array}$ & $\begin{array}{l}0.003 \\
0.001\end{array}$ & $\begin{array}{l}0.080^{*} \\
0.109^{\star}\end{array}$ \\
\hline & $n=6$ days & 0.000 & 0.020 & 0.003 \\
\hline & $\begin{array}{l}\mathrm{n}=9 \text { aays } \\
\mathrm{n}=12 \text { days }\end{array}$ & 0.000 & $0.279^{*}$ & $0.0124^{*}$ \\
\hline & $\mathrm{n}=15$ days & 0.000 & $0.212^{*}$ & $0.093^{*}$ \\
\hline \multirow[t]{3}{*}{ Air Temperature } & $\mathrm{n}=9$ days & $0.101^{*}$ & 0.001 & 0.002 \\
\hline & $\mathrm{n}=12$ days & 0.027 & $0.062^{*}$ & $0.142^{\star}$ \\
\hline & $\mathrm{n}=15$ days & $0.091^{\star}$ & $0.211^{*}$ & $0.081^{\star}$ \\
\hline \multirow{2}{*}{ Water Temperature } & $\begin{array}{l}\mathrm{n}=18 \text { days } \\
\mathrm{n}=3 \text { days }\end{array}$ & $\begin{array}{l}0.027 \\
0.062^{*}\end{array}$ & $\begin{array}{l}0.072^{*} \\
0.000\end{array}$ & $\begin{array}{l}0.002 \\
0.000\end{array}$ \\
\hline & $\mathrm{n}=6$ days & 0.019 & 0.000 & 0.000 \\
\hline Salinity & $\begin{array}{l}\mathrm{n}=3 \text { days } \\
\mathrm{n}=6 \text { days }\end{array}$ & - & - & $\begin{array}{l}0.000 \\
0.002\end{array}$ \\
\hline
\end{tabular}

Source : Primary Data

* unsignificant on $\alpha=0.05 \mathrm{n}=$ average day on 
collection while air temperature on average 15 days. Next on brackish water habitat, the rainfall significantly affect mosquito larva density on average 6 days and 9 days before collection while air temperature on average 9 days and 18 days. Next the water temperature and salinity significantly affect on average 3 days until 6 days. While the Anophels sp mosquito larva density on semi permanent habitat significantly affected by rainfall since the day of larva collection until average 6 days. For air temperature significant on average 12 days and 15 days while water temperature significantly affect larva density on average 3 days until 6 days before larva collection.

The enormity of climate factor and habitat characteristic effect to Anophels sp mosquito larva density on each habitat type is depended on determinant coefficient value. The higher the determinant coefficient value, then the higher the variable effect. Determinant coefficient value is obtained from linear regression test result or non linier form of 2 nd order polynomial. Tested variables are they which significantly affect larva density. Regression test result on fresh water habitat indicates that the rainfall affects the larva density level liniernegatively by $25 \%-58 \%$. This means larva density on fresh water permanent habitat is inversely comparable with rainfall amount. Similar relation was obtained on a research in Eritrea (Shililu, 2007). Meanwhile air temperature and water temperature affect larva density linier possitively by $19 \%$ and $23 \%$ each. Warm water temperature on fresh water permanent habitat will accelerate egg hatching so that it could add the number of larva density. Parameter value and regression model on fresh water habitat are presented on table 3.
For relation between climate factor and habitat characteristict with mosquito larva density on brackish water habitat indicates two different trend, which are 2nd order polynomial and negative linier. The rainfall affect larva desity polynomially by $35 \%-61 \%$. This means on certain condition, rainfall can increase or decrease larva density. While air temperature affect larva density liniearly by $14 \%$ and $21 \%$ as water temperature and salinity by $20 \%-33 \%$ and $24 \%$ - $25 \%$ each. The effect of rainfall mostly occured on average 6 days while air temperature on average 9 days before larva collection. For water temperature effect mostly occured on average 6 days while salinity on average 3 day before collection. The parameter value and regression model on brackish water habitat can be seen on table 4 .

Similar with brackish water habitat, the regression test result on semi permanent habitat also shown negative linear trend and 2nd order polynomial. It means, polinomially, larva density is affected by rainfall by $34 \%$ $65 \%$ on larva collection day until average 6 days before. As air temperature affect larva density by negative linear as much as $13 \%$ on average 9 days before larva collection. Same relation is indicated by water temperature. Largest effect of it occured on average 3 days before larva collection by $62 \%$. Climatologically there is positive correlation between air temperature and water temperature. Water temperature variation tends to increase following the pattern of air temperature on scale of daily, weekly and monthly (Ali, 2013). The higher air temperature, the higher water temperature will be, though it is vary on each type of habitat. Generally water temperature on shallow water tends to increase faster compare to deep water.

Table 3. Parameter value and regression model between Rain Fall (RF), Air Temperature (AT) and Water Temperature (WT) on Anophels sp larva density (LD) on fresh water permanent habitat.

\begin{tabular}{llll}
\hline Variable & $\mathrm{r}^{2}$ & Relation type & Regression equation \\
\hline Rainfall $(\mathrm{n}=3)$ & 0.39 & Negative Linier Trend & $\mathrm{LD}=-0.0422 \mathrm{RF}+2.8394$ \\
Rainfall $(\mathrm{n}=6)$ & 0.58 & Negative Linier Trend & $\mathrm{LD}=-0.0726 \mathrm{RF}+3.0287$ \\
Rainfall $(\mathrm{n}=9)$ & 0.34 & Negative Linier Trend & $\mathrm{LD}=-0.0661 \mathrm{RF}+2.9993$ \\
Rainfall $(\mathrm{n}=12)$ & 0.25 & Negative Linier Trend & $\mathrm{LD}=-0.0834 \mathrm{RF}+3.1333$ \\
Rainfall $(\mathrm{n}=15)$ & 0.26 & Negative Linier Trend & $\mathrm{LD}=-0.0884 \mathrm{RF}+3.1393$ \\
Air Temp $(\mathrm{n}=12)$ & 0.19 & Positive Linier Trend & $\mathrm{LD}=0.1983 \mathrm{AT}-3.557$ \\
Water Temp $(\mathrm{n}=6)$ & 0.23 & Positive Linier Trend & $\mathrm{LD}=0.4541 \mathrm{WT}-12.28$ \\
Source Primary Data & & & \\
n=average on day- & &
\end{tabular}


Table 4. Parameter value and regression model between Rain Fall (RF), Air Temperature (AT), Water Temperature (WT) ane Salinity (S) to Anophels sp Larva Density (LD) on brackish water permanent habitat and semi permanent habitat

\begin{tabular}{|c|c|c|c|c|}
\hline \multicolumn{2}{|l|}{ Variable } & $\mathrm{r}^{2}$ & Relation & Regression Equation \\
\hline \multicolumn{5}{|c|}{ Brackish water permanent habitat } \\
\hline \multirow{2}{*}{\multicolumn{2}{|c|}{$\begin{array}{l}\text { Rain Fall }(n=6) \\
\text { Rain Fall }(n=9) \\
\text { Air Temperature }(n=9)\end{array}$}} & 0.61 & Polynomial Trend & $+0.2949 R F+0.2148$ \\
\hline & & $\begin{array}{l}0.35 \\
0.21\end{array}$ & $\begin{array}{l}\text { Polynomial Trend } \\
\text { Negative Linear Trend }\end{array}$ & $\begin{array}{l}\mathrm{LD}=-0.0118 \mathrm{RF}^{2}+0.3112 \mathrm{RF}+0.1675 \\
\mathrm{LD}=-0.6685 \mathrm{AT}+21.935\end{array}$ \\
\hline \multirow{2}{*}{$\begin{array}{l}\text { Air } \\
(\mathrm{n}=18) \\
\text { Water }\end{array}$} & Temperature & 0.14 & Negative Linear Trend & $\mathrm{LD}=-2.0652 \mathrm{AT}+58.645$ \\
\hline & Temperature & 0.20 & Negative Linear Trend & $\mathrm{LD}=-0.6023 \mathrm{WT}+21.257$ \\
\hline \multirow{2}{*}{$\begin{array}{l}(\mathrm{n}=3) \\
\text { Water } \\
(\mathrm{n}=6) \\
\text { Salinity }\end{array}$} & Temperature & 0.33 & Negative Linear Trend & $\mathrm{LD}=-1.0485 \mathrm{WT}+33.377$ \\
\hline & $n=3)$ & 0.25 & Neg & $0150 \mathrm{~S}$ \\
\hline \multicolumn{2}{|c|}{ Salinity $(n=6)$} & 0.24 & Linear Trend & 6818 \\
\hline \multicolumn{5}{|c|}{ Semi permanen habitat } \\
\hline \multicolumn{2}{|c|}{ Rain fall $(n=1)$} & 0.36 & Polynomial Trend & $\mathrm{LD}=-0.0043 \mathrm{RF}^{2}+0.1547 \mathrm{RF}+0.4729$ \\
\hline \multicolumn{2}{|c|}{$\begin{array}{l}\text { Rain fall }(n=3) \\
\text { Rain fall }(n=6)\end{array}$} & $\begin{array}{l}0.65 \\
0.34\end{array}$ & nial Trend & $\begin{array}{l}\mathrm{LD}=-0.009 \mathrm{RF}^{2}+0.2697 \mathrm{RF}-0.0379 \\
\mathrm{LD}=-0.011 \mathrm{RF}^{2}+0.2724 \mathrm{RF}-0.0393\end{array}$ \\
\hline \multicolumn{2}{|c|}{ Suhu udara $(n=9)$} & 0.13 & Negative Linear Trend & $\mathrm{LD}=-1.8043 \mathrm{AT}+51.007$ \\
\hline \multirow{2}{*}{$\begin{array}{l}\text { Water } \\
(\mathrm{n}=3) \\
\text { Water } \\
(\mathrm{n}=6)\end{array}$} & Temperature & 0.62 & Negative Linear Trend & $\mathrm{LD}=-0.7 \mathrm{WT}+24.115$ \\
\hline & Temperature & 0.42 & Negative Linear Trend & $\mathrm{LD}=-1.6026 \mathrm{WT}+53.546$ \\
\hline
\end{tabular}

Source : Primary Data

$\mathrm{n}=$ average on day-

Since then the Anophels sp mosquito larva on shallow water habitat type is more sensitive to water temperature. The parameter value and regression model on semi permanent habitat are presented on table 4 .

Based on observation result and analysis conducted, it can be known that climate factor and habitat characteristic that most dominant in affecting the Anophels sp mosquito larva density level on aquatic habitat on Koya Barat is rainfall, air temperature, water temperature and salinity. Those parameters can give whether positive or negative effect to larva density on each habitat. Positive effect will increase larva density while negative effect will decrease it. In controlling and eradicating of infecting vector mosquito, negative effect from climate factor and environment parameter are highly expected since they can reduce the larva population on aquatic habitat. When larva population is reduced, then mature mosquito density will decrease as well. By then, the possibility of mosquito's bite and malaria disease infection are smaller. Generally malaria disease always positively correlated with vector density. The higher vector density, then malaria disease infection will be higher and vice versa.
This has been proved on two ecosystem which are swamp and beach (Kawulur, 2014)

Considering the climate factor and habitat environment characteristic has real effect on Anophels sp mosquito larva density, then these two factors should be considered in controlling malaria vector based on climate and environment on Koya Barat sub district. There are several things can be done to decrease mosquito larva density, like open a channel on innundated water, particularly on habitat that does not utilized to preserve fish or grow kale. While on preservation habitat can use larvacide made of natural ingredients, like soursop leaf extract. This larvacide has been proven to exterminate mosquito larva more effectively by using $6.89 \%$ concentration within 6 hours (Harfriani, 2012). The application of larvacide on close current type permanent habitat better be done when does not rain or low rainfall since on that condition mosquito larva will increase. Yet, during high rainfall period, the application of larvacide better be avoided since naturally the mosquito egg and larva will be wasted by water current. Next step can be done is to clean water vegetation so that the habitat is exposed by direct sunlight. It will increase water 
temperature so that mosquito larva is naturally eradicated, particularly for larva species that can't be adapted with warm water temperature.

Based on identification result, there are three kind of Anophels mosquito larva species that live on three type of aquatic habitat on Koya Barat. They are An. farauti (43\%), An. punctulatus (31\%) and An. koliensis (26\%). These three species are malarian vector in east of Indonesia including Papua (Munif, 2009). The Anophels farauti larva is the only species that able to live on all type of habitat, whether permanent or not, fresh water or brackish water. The research (Sandy et al., 2017) in Kelaan and Kilmasa, Maluku Tenggara Barat also found out Anophels farauti larva live on fresh water or brackish water habitat. While two other species only found on fresh water habitat.

\section{Conclussion}

There are four parameters that significantly affect Anophels sp mosquito larva density on three type of aquatic habitat on Koya Barat subdistrict, Muara Tami district, Jayapura which are rainfall, air temperature, water temperature and salinity. Larva density on fresh water permanent habitat is affected negative linearly by rainfall as much as $25 \%$ $58 \%$. The rainfall effect occurs on avera 3 days to 15 days before larva collection. While water temperature and air temperature affect larva density positive linierly as much as $23 \%$ and $19 \%$ on average 6 days and 12 days before larva collection. Next, larva density on brackish water permanent habitat is affected by rainfall 2nd order polynomially on average 6 days until 9 days before larva collection as much as 35\%-61\% while air temperature affect negative linearly by $14 \%-21 \%$ on average 9 days and 18 days before larva collection with the effect as much as $20 \%-33 \%$ and $24 \%-25 \%$. For larva density on semi permanent habitat is affected by rainfall 2 nd order polynomially on the day of larva collection until average 6 days before larva collection as much as $34 \%-65 \%$. And for air temperature and water temperature affect larva density negative linearly. The effect of air temperature as much as $13 \%$ on average 9 days before larva collection while effect of water temperature as much as $42 \%-62 \%$ on average 3 days until 6 days before larva collection. The role of climate factor and habitat environment characteristic need to be considered in controlling the vector to cut off pre mature mosquito cycle on aquatic habitat of Koya Barat subdistrict.

\section{References}

Abowei, J. F. N. 2010. Salinity, dissolved oxygen, pH and surface water temperature conditions in Nkoro River, Niger Delta, Nigeria. Advance Journal of Food Science and Technology, 2(1): $36-40$.

Ali, S. 2013. Estimation of surface water temperature in small recharge pond from air temperature. Indian Journal of Soil Conservation, 41(1):. $1-7$.

Bayoh, M. N. and Lindsay, S. W. 2004. Temperaturerelated duration of aquatic stages of the Afrotropical malaria vector mosquito Anopheles gambiae in the laboratory. Medical and Veterinary Entomology, 18(2): 174-179.

Duarsa, A. B. S. .2008. Dampak Pemanasan Global Terhadap Risiko Terjadinya Malaria. Jurnal Kesehatan Masyarakat, 2(2):181-185.

Githeko, A. K. et al. .2000. Climate change and vector-borne diseases: A regional analysis. Bulletin of the World Health Organization, 78(9): 1136-1147.

Goswami, P. et al. 2012. A Model of Malaria Epidemiology Involving Weather, Exposure and Transmission Applied to North East India. PLoS ONE, 7(11).

Hakim, L. and Ipa, M. 2007. Sistem Kewaspadaan dalam KLB Malaria Berdasarkan Curah Hujan, Kepadatan Vektor dan Kesakitan Malaria di Kabupaten Sukabumi. Media Litbang Kesehatan, XVII(2): 34-40.

Harfriani, H. 2012. Efektivitas larvasida ekstrak daun sirsak dalam membunuh jentik nyamuk. Jurnal Kesehatan Masyarakat, 7(2): 164-169.

Kawulur, et.al. 2014. Anopheles farauti Population Density and Biting Behaviour in Conjunction with Malaria Cases on the Coastal Ecosystems of Biak Numfor Regency and the Swamp Ecosystems of Asmat Regency. Biota, 19(1): 27-35.

Kementrian Kesehatan .2017. Profil Data Kesehatan Indonesia Tahun 2015. Jakarta: Kementerian Kesehatan RI.

Mardiana and Fibrianto D. 2009. Hubungan Karakteristik Lingkungan Luar Rumah Dengan Kejadian Penyakit Malaria. Jurnal Kesehatan Masyarakat, 5(1): 11-16.

Munif, A. 2009. Nyamuk vektor malaria dan hubungannya dengan aktivitas kehidupan manusia di Indonesia. Aspirator, 1(2): 94- 
102.

Paaijmans, K. P. et al. 2010. Relevant microclimate for determining the development rate of malaria mosquitoes and possible implications of climate change. Malaria Journal, 9(1):. 196

Sandy, S. et al. 2017. Entomological Surveillance of Malaria Vectors in Saumlaki, Maluku Tenggara Barat Regency, Maluku Province. Jurnal Kesehatan Masyarakat, 12(2):. xx-xx.

Shililu, J. et al. 2007. Mosquito larval habitats in a semiarid ecosystem in Eritrea: Impact of larval habitat management on Anopheles arabiensis population. American Journal of Tropical Medicine and Hygiene, 76(1): 103110.

Sugiarto et al. 2016. Karakteristik Habitat Larva anopheles spp. di Desa Sungai Nyamuk, Daerah Endmik Malaria di Kabupaten
Nunukan, Kalimantan Utara. BALABA, 12(1): 47-54.

Surendran, S. N., Jude, P. J. and Ramasamy, R. 2011. Variations in salinity tolerance of malaria vectors of the Anopheles subpictus complex in Sri Lanka and the implications for malaria transmission. Parasites \& vectors, 4: 117.

Suwito, et al. 2010. Hubungan Iklim, Kepadatan Nyamuk Anopheles dan Kejadian Penyakit Malaria. J. Entomol. Indon, 7(1): 42-53.

Zhou, G. et al. 2004. Association between climate variability and malaria epidemics in the East African highlands. Proceedings of the National Academy of Sciences, 101(8): 23752380 . 